\title{
Use of the Greater Duckweed as feed for the Tilapia fish
}

\author{
Bindu Pokharel (Bhattarai) ${ }^{*}$, Bhabindra Niroula and Sasinath Jha \\ Department of Botany, Post Graduate Campus, T.U., Biratnagar, Nepal \\ E-mail: bindupokharel.bp@gmail.com
}

\begin{abstract}
The fresh weight gain of the Nile tilapia individuals reared on different feeds for 21 days occurred in the order: conventional feed $(65 \%)>$ conventional feed and duckweed powder in equal proportion (37\%) > duckweed powder $(09 \%)$. The conventional feed and duckweed powder were insignificantly different from each other in protein and phosphorus, but significantly different $(\mathrm{P}<0.05)$ in fat, total ash and calcium contents. The tilapia individuals reared on the mixture of the conventional feed and duckweed powder had significantly $(\mathrm{P}<0.05)$ highest concentration of proteins $(50.3 \%)$ than those reared on either conventional feed $(45.34 \%)$ or duckweed powder $(45.79 \%)$ alone.
\end{abstract}

Key words: Nutrients, Oreochromis niloticus, Spirodela polyrhiza

\section{Introduction}

The Nile tilapia is a cichlid fish native to Africa but nowadays cultured in Nepal's Terai region also. It is a highly nutritious fish, rich in omega 3 oil which is good for patients with heart ailments. The fish contains less bone than other common fish and has a good taste, making it popular among fish lovers. It can survive extreme conditions like low oxygen and abrupt changes in temperature (Kingdon, 1989).

In general, protein component in fish feeds is a very essential factor affecting growth performance of fish and feed cost. The easily available duckweeds (the smallest aquatic angiosperms/Lemnaceae) can solve the problem as they are rich in protein and dietary minerals and low in fiber. They do not produce toxic alkaloids and are palatable to a wide variety of domestic animals and fish (Landolt \& Kandeler, 1987). Hence, the present study was undertaken to evaluate the comparative effects of conventional feed (CF) alone, mixture of $\mathrm{CF}$ and greater duckweed powder (GD) in 1:1 ratio, and GD alone on the growth and nutrient concentrations of the tilapia fish.

\section{Materials and Methods}

The tilapia fingerlings (length $9.97 \mathrm{~cm}$, breadth $2.96 \mathrm{~cm}$, weight $13.43 \mathrm{~g}$ ) were obtained from the Fishery Section of the Nepal Agricultural Research Council (Tarahara Branch, Sunsari District) and transported to the Bigyan Bhawan (PG Campus, Biratnagar) in polythene bags partially filled with water and oxygen. They were released in a concrete tank for acclimatization for two days. Nine transparent glass aquaria (size $45 \mathrm{~cm}$ x $30 \mathrm{~cm} \mathrm{x}$ $30 \mathrm{~cm}$ ) filled up to two-third volume with borewell water and having aeration facilities were employed for rearing tilapia fingerlings ( 3 individuals per aquarium) in three sets of different diet. In the first set of three aquaria, the fish received only the CF; in the second set they received the mixture of CF and GD; whereas only GD was provided to the fishes in the third set of aquaria. Specified diet was provided daily at the rate of $20 \%$ of the body 
weight of the fish following Kabir et al. (2009). Water in each aquarium was replaced with fresh borewell water at 2 days intervals. The experiment was conducted between February 3-24, 2017 during which the minimum and maximum atmospheric temperatures were 15.5 and $30^{\circ} \mathrm{C}$, respectively.

Among the feeds, CF was prepared by mixing wheat flour, soybean flour and powdered local fishes in 2:2:1 ratio, whereas for GD, Spirodela biomass, collected from a pool adjacent to the PG Campus, Biratnagar, was washed, dried in oven at $80^{\circ} \mathrm{C}$ to a constant weight, and grinded to powder in an electric grinder. AOAC's (1990) methods were followed for all the biochemical analyses.

\section{Results and Discussion}

Tilapia reared solely on CF had the highest increment in weight $(65 \%)$ in comparison to those reared on the mixture of CF and GD (37\%) or GD (9\%) alone (Table 1). The fish reared on $\mathrm{CF}$ alone were golden-white, while those reared on the mixture of $\mathrm{CF}$ and GD, and GD alone were white and blackish in appearance, respectively. Comparatively, CF had significantly higher $(\mathrm{P}<0.05)$ concentration of fats although total ash and calcium were significantly $(\mathrm{P}<0.05)$ higher in GD. However, proteins and phosphorus were slightly more in CF than the GD (Table 2).

Table 1. Morphological variations in Nile tilapia reared on different feeds for 21 days. (mean $\pm S E$; $\mathrm{n}=3)$

\begin{tabular}{llcccc}
\hline & Appearance & $\begin{array}{c}\text { Length } \\
(\mathbf{c m})\end{array}$ & $\begin{array}{c}\text { Breadth } \\
(\mathbf{c m})\end{array}$ & $\begin{array}{c}\text { Weight } \\
(\mathbf{g})\end{array}$ & $\begin{array}{c}\text { Growth in- } \\
\text { crement (\%) }\end{array}$ \\
\hline Conventional feed (CF) & Golden-white & $11.23 \pm 1.93$ & $3.73 \pm 1.11$ & $22.19 \pm 2.72^{*}$ & $65 \pm 5^{*}$ \\
Greater duckweed (GD) & Blackish & $10.10 \pm 1.83$ & $3.73 \pm 1.05$ & $14.64 \pm 2.21$ & $09 \pm 2$ \\
CF + GD & White & 10.231 .84 & $3.16 \pm 1.10$ & $18.40 \pm 2.47 *$ & $37 \pm 4^{*}$ \\
\hline
\end{tabular}

* Means significantly different $(\mathrm{P}<0.05)$

Table 2. Nutrients $(\%)$ in $\mathrm{CF}$ and GD (mean $\pm \mathrm{SE} ; \mathrm{n}=3$ )

\begin{tabular}{cccccc}
\hline & Fats & Proteins & Total Ash & Calcium & Phosphorus \\
\hline GD & $1.56 \pm 0.72$ & $19.21 \pm 2.52$ & $22.99 \pm 2.76^{*}$ & $0.84 \pm 0.53^{*}$ & $0.27 \pm 0.30$ \\
CF & $7.89 \pm 1.62 *$ & $22.98 \pm 2.76$ & $4.27 \pm 1.19$ & $0.13 \pm 0.20$ & $0.40 \pm 0.36$ \\
\hline \multicolumn{7}{c}{ * Means significantly different $(\mathrm{P}<0.05)$}
\end{tabular}

Tilapia reared on the mixture of $\mathrm{CF}$ and GD contained more proteins $(50.3 \%)$ than those reared on $\mathrm{CF}(45.34 \%)$ or GD $(45.79 \%)$ alone. However, calcium and phosphorus concentrations were significantly $(\mathrm{P}<0.05)$ highest in the fish reared on the $\mathrm{CF}$ in comparison to those reared on the mixture of CF and GD as well as GD alone (Table 3).

Table 3. Nutrient accumulation $(\%)$ in fish reared on different feeds (mean $\pm \mathrm{SE} ; \mathrm{n}=3$ )

\begin{tabular}{lccccc}
\hline & Fats & Proteins & Ash & Calcium & Phosphorus \\
\hline CF & $10.09 \pm 1.83$ & $45.34 \pm 3.88$ & $20.25 \pm 2.60$ & $0.56 \pm 0.43^{*}$ & $0.39 \pm 0.36^{*}$ \\
CF + GD & $11.32 \pm 1.94$ & $50.30 \pm 4.09$ & $19.24 \pm 2.53$ & $0.42 \pm 0.37 *$ & $0.24 \pm 0.28$ \\
GD & $11.44 \pm 1.95$ & $45.79 \pm 3.91$ & $18.24 \pm 2.46$ & $0.21 \pm 0.26$ & $0.31 \pm 0.32$ \\
\hline \multicolumn{5}{c}{ * Means significantly different $(\mathrm{P}<0.05)$}
\end{tabular}


It may be inferred from the present study that the freely available greater duckweed can partially substitute the costly commercial feed in tilapia culture which is in agreement with the previous findings on other duckweeds (Gaigher et al., 1984; Kabir et al., 2009).

\section{Acknowledgements}

Authors are thankful to the Nepal Agricultural Research Council (Tarahara Branch, Sunsari District) for the generosity in providing tilapia fingerlings for the present study. Thanks are also due to the Head, Department of Botany, Post Graduate Campus, Biratnagar for facilities.

\section{References}

AOAC 1990. Official methods of analysis, $\left(13^{\text {th }}\right.$ ed.). Association of Official Analytical Chemists, Washington DC.

Gaigher, I.G., D. Porath \& G. Granoth 1984. Evaluation of duckweed (Lemna gibba) as feed for tilapia (Oreochromis niloticus x O. aureus) in a recirculating unit. Aquaculture 41: 235244.

Kabir, A.N., M.A. Hossain \& M.S. Rahman 2009. Use of duckweed as feed for fishes in polyculture. Journal of Agriculture and Rural Development 7(1-2): 157-160.

Kingdon, J. 1989. Island Africa: The evolution of Africa's rare plants and animals. Princeton University Press, New Jersey.

Landolt, E. \& R. Kandeler 1987. The family of Lemnaceae- A monographic study: Phytochemistry, physiology, application and bibliography, vol. 4. Veroffentlichungen des Geobotanisches Institut der ETH, Stiftung Ruebel, Zurich. 